Article

\title{
"Refugees" as a Misnomer: The Parochial Politics and Official Discourse of the Visegrad Four
}

\author{
Artur Gruszczak \\ Department of National Security, Jagiellonian University, Poland; E-Mail: artur.gruszczak@uj.edu.pl
}

Submitted: 26 April 2021 | Accepted: 2 July 2021 | Published: 28 October 2021

\begin{abstract}
Attitudes towards migrants and refugees are created and reflected at the level of public policies, as well as in local communities which cultivate traditional approaches and a specific worldview. The refugee crisis in Europe in the mid-2010s showed how public opinion translated into voting behaviour and became a source of strength for nationalist anti-immigrant movements and parties across the continent. East-Central Europe was no exception, regardless of the absence of a long-term, massive inflow of refugees. Nevertheless, the migration crisis created a new political narrative which exploited deeply rooted resentments, complexes, and fears. This article aims to analyse the official policy responses to the refugee crisis in the four East-Central European countries: Poland, Hungary, Slovakia, and the Czech Republic, which together constitute the so-called Visegrad Four. It puts the emphasis on the discriminatory practice of misnaming the refugees, which became deeply anchored in the political discourse of these countries. Based on a qualitative content analysis supplemented by the findings of public opinion polls, the argument developed in the article is that reluctant and defensive attitudes towards the refugees have been determined by the revival of parochialism as a radical reaction to the challenges of global trends and supra-local processes. The theoretical framing of the refugee problem is built on politicization, in connection with the concept of parochialism, seen from political and social perspectives, and the meaning of the use of the misnomer as a policy instrument. The article concludes that the migration crisis petrified traditional cleavages at the supra-local level, reinforcing simultaneously the sense of parochial altruism and hostility towards "the other."
\end{abstract}

\section{Keywords}

anti-refugee discourse; migration; misnomer; parochialism; politicization; public discourse; refugees; Visegrad Four

\section{Issue}

This article is part of the issue "Migration and Refugee Flows: New Insights" edited by Inmaculada Martínez-Zarzoso (University of Göttingen, Germany / Jaume I University, Spain).

(C) 2021 by the author; licensee Cogitatio (Lisbon, Portugal). This article is licensed under a Creative Commons Attribution 4.0 International License (CC BY).

\section{Introduction}

The refugee crisis in Europe has fuelled nationalist and xenophobic attitudes among citizens of the European Union. "The politics of phobias" (Taras, 2009, pp. 83-86; cf. Bauman, 2004, p. 99) unwrapped the dynamics of ethnocentric and discriminatory campaigns against immigrants. It emboldened right-wing populist parties to unleash a new wave of xenophobic mobilisation against "the enemy from abroad" (Pelinka, 2013, p. 9) by creating fear of the consequences of immigration (Wodak, 2015). Public opinion translated into voting behaviour and political decisions became a source of strength for national- ist anti-immigrant movements and parties across Europe. East-Central Europe is no exception, although the region has not experienced a long-term, massive inflow of these refugees thus far. However, the issue of immigrants coming to Europe from the Middle East and Africa has left a deep mark on political discourse and for now has brought about specific political consequences. A new political narrative has exploited deeply rooted resentments, complexes, and fears, which has led to the politicisation and securitisation of the migration and refugee issues. East-Central Europe is one of the arenas of the public discourse on immigration and the international protection of refugees. The political arena has been stigmatized 
by ethno-nationalist narratives, projected onto societies by governments and some nationalist and populist political parties.

This article aims to analyse and explain the radical policy response to the Europe-wide refugee crisis in East-Central Europe in the mid-2010s. The growing resentment against immigrants accompanied the exceptional inflow of "strangers" from Asian and African countries. Regardless of the unprecedented scale of the migration crisis, popular preferences for fending off foreigners and preserving national integrity were nothing unusual; they had occurred on various occasions in Europe prior to the developments of the mid-2010s. Ethnocentric, xenophobic and racist attitudes have been intensified in times of emergency caused by internal cleavages, integration challenges, and external pressures (De Master \& Le Roy, 2000; Gibson, 2002; Hargreaves \& Leaman, 1995; Levy, 2010; Van der Brug et al., 2000; Wistrich, 1999).

Against that background, the case of the four EastCentral European countries-Poland, Hungary, Slovakia, and the Czech Republic, which together constitute the so-called Visegrad Four (or the Visegrad Group)-is taken up for three reasons. Firstly, the governments of the Visegrad Four adopted an uncompromising stance against refugees and coordinated their policies on the regional level. Secondly, they deliberately disavowed the rights of refugees by considering them a sub-category of voluntary migrants. Accordingly, they expunged the term "refugee" from the official discourse of migration. Thirdly, the semantic eradication of refugees was a deliberate ploy for deflecting criticism of intolerance towards exiles and the de-legitimisation of asylum seekers.

The article puts the emphasis on the discriminatory practice of misnaming the refugees, which became deeply anchored in the political discourse of the four East-Central European countries. While the method of applying alternative terms for refugees to the public discourse has usually accompanied refugee crises (see Bello, 2017, pp. 55-59; Long, 2013; Zetter, 1991, 2007), the Visegrad Four's enduring and reckless disregard for the ontological status of refugees has been exceptional, especially in comparison with the other EU member states. The latter highlighted the issue of refugees and the EU's asylum policy during the migration crisis by pointing to its legal, political, institutional, and financial determinants. The very term "refugee" was present in many varieties in official documents adopted by the EU institutions and issued by national governments of the member states (Menéndez, 2016, pp. 395-407; Morsut \& Kruke, 2018, pp. 149-155; Niemann \& Zaun, 2018; Sigona, 2018, pp. 457-458)-except for the Visegrad Four.

The aversion to refugees underpinning that practice should be interpreted as a behavioural trait of parochial politicians in East-Central Europe. Consequently, parochialism is considered as a post-Communist antimodernisation backlash against the consequences of globalisation and cosmopolitanism (cf. Malešević, 2004, pp. 115-117).
The adopted time frame encompasses the climax of refugee inflow to European countries in 2015 and subsequent developments lasting to the evident subsiding of the migratory wave in 2017.

The conceptual framing of the refugee problem in connection with parochialism has been built on politicisation, conceived as the making of a matter a subject of public dispute within the political system (see De Wilde, 2011; De Wilde \& Zürn, 2012, p. 139; Grande \& Hutter, 2016, pp. 7-8). In East-Central Europe the issue of refugees was politicised by the governments through discursive shifts towards discriminatory opinions about refugees and immigrants (Krzyżanowski, 2017; Krzyżanowski et al., 2018, pp. 4-6). The contours of political ethnography (Kubik, 2009; Schatz, 2009) can be noticed wherever particularism, localism, familism, in-group homogeneity and exclusionary practices are highlighted. In that context, the concept of parochial altruism is applied to capture the "we" versus "them" divide (see Leudar et al., 2004, 2008) as a combination of social solidarity and cooperative engagement with discriminatory tendencies and hostility towards other groups. Parochial altruism as a motivational factor behind conflicting identities and political cleavages is confronted with regional integration processes in Europe. Internal divisions in the EU, which facilitated ethnopolitical mobilization and populism, contributed to the perception of parochialism as "false uniqueness" (Buhari-Gulmez \& Gulmez, 2020). Accordingly, parochial Europe was conceptualised as a single and exceptional polity that inspires instrumental loyalties, and rewards provincial actors for their dedication and engagement in local affairs. The hypothetical assumption that the rejection of refugees by parochial actors, motivated by the exclusionary and confrontational nature of parochial altruism, is strengthened by the application of the concept of the misnomer. Based on Sartori (1991), Rancière (1992, 1999), and Hadland (2002), a misnomer is interpreted as a premeditated political tool for the denial of a true identity to the individual. Hence, the misnaming of refugees serves to strip them of their political, legal, and human rights.

Concerning the method, this study employs an interpretive political analysis approach (Schwartz-Shea \& Yanow, 2012; Yanow, 2000) to the study of public discourse. It is based on a qualitative content analysis of 64 texts (transcripts), embracing public speeches, official statements, and joint declarations adopted in the years 2015-2017. The samples were carefully selected according to their substance (reference to migration and refugee matters), political status (top-level politicians) and impact on public opinion (approval ratings). Selected documents adopted by the Visegrad Group were included in the text corpus. "Refugee" was determined to be the keyword; synonyms and related words ("migrant," "immigrant," "asylum seeker", and their derivatives) served as referential terms. Transcripts were tagged manually. The examination of the texts 
was focused on the contextual absence of the keyword and its relational analysis (Krippendorff, 2003, pp. 66-68). The most illustrative examples of the antirefugee discourse were interpreted within the framework of parochial politics. The findings of the content analysis were supplemented by data from public opinion polls.

The argument developed in the article is that reluctant and defensive attitudes towards the refugees in the Visegrad countries have been determined by the revival of parochialism as a radical reaction to the challenges of cultural modernisation in post-Communist societies. The argument holds that the politicisation of the topic of refugees in official discourse caused a discriminatory practice of misnaming them and denigrating them as public foes.

The article proceeds as follows. First, it presents the conceptualisation of parochialism in the contexts of political, sociological, and European integration studies. It explains the meaning of parochial altruism and interprets it against the backdrop of European integration. It then introduces the term "misnomer," clarifying its semantic content and utility for the interpretation of parochial politics. The next section explains the use of the term "refugee" as a misnomer by top political decisionmakers in the Visegrad countries for the management of the refugee crisis in the mid-2010s. This is followed by another case of the misnaming of refugees based on ethno-cultural and religious factors: The figure of the "Arab" as equivalent to a refugee is interpreted with reference to political discourse and public opinion polls.

\section{Parochial Politics and the Role of Misnomers}

Parochialism is commonly seen as an anachronistic remnant of the past, an anti-modernist posture characterized by a narrowness of views, keen interest in local affairs, petty provincialism, and the lack of a global perspective (Parochialism, 2005). Rephrasing the environmental slogan, parochialism recommends that we "think locally, act locally." Parochialism is conceived as an individual or group attitude towards social reality which structures collective behaviour around local, indigenous, and inner-circle affairs. It is associated in the social sciences with a tendency to focus on issues that are being debated within a given group, a community, or a society (Poulson \& Campbell, 2010, p. 32). From a political culture perspective, parochialism is marked by a passive attitude towards the political system, the diffusion of roles along political, economic, and religious orientations, and a focus on autonomous local communities (Almond \& Verba, 1989, p. 17). From a social network perspective, parochialism, as Bowles and Gintis (2004, p. 18) argue, "makes networks not only smaller, but more homogeneous as well, corresponding efficiencyenhancing effects of similarity or social affinity with parochial networks may be important." However, ingroup relative homogeneity determines ways of belong- ing and fosters exclusionary practices. As De Dreu et al. (2014, p. 4) put it, "parochial cooperation is motivated by, and manifested in (1) protecting and promoting the in-group (henceforth in-group love), and (2) derogating and fighting more or less rivalling out-groups (henceforth out-group hate)." Due to that, parochial behaviour is identified with particularism, localism, familism, and un-civic loyalties. It endorses sentiments and practices underpinning archaic social distinctions and intolerance of strangers (Bowles \& Gintis, 2004, p. 3). Concurrently, parochialism prefers in-group homogeneity and reduces the pool of potential outsiders that can migrate into the network (Bowles \& Gintis, 2004, p. 9; Poulson \& Campbell, 2010). Thus, social exclusion is inscribed in the group logic of parochialism and reduces tolerance and the diversity of interactions within a given group, as well as with external actors.

Parochialism stands in a stark opposition to a cosmopolitan perspective. Parochial life is situated on the grass-roots level. It addresses local actors (autonomous local authorities, religious leaders, grassroots activists) and, if necessary, local representatives of central authorities or nation-wide political parties and social movements (Della Porta \& Diani, 2006, p. 168; Tilly, 1986, pp. 391-392). Bowles and Gintis (2004) argue that parochialism, as an endogenously determined network of interactions, increases specific problem-solving capacities. Specifically, parochialism arouses altruistic sentiments within a community or social group bound by kinship, ethnicity, race, cultural affinity, or national identity. In-group altruism promotes mutual trust and reduces communication difficulties. The intersection of parochialism and altruism, aptly conceptualised by Choi and Bowles (2007, pp. 636-640), addresses the social solidarity and group benefits resulting from hostility towards other groups. Parochial altruism is based on a combination of in-group tendencies to discriminate and cooperatively engage in violent aggression against out-group members (De Dreu et al., 2015; Rusch, 2014). Parochial altruists "give preferentially to their own members and punish those who harm group members more severely than if the victim is not an insider" (Choi \& Bowles, 2007, p. 638). Parochial behaviour, consisting in preferences for favouring the members of one's own social group, is altruistically internalized through egalitarian norm taking and expressed by a determination to enter conflict with norm-breakers and punish them for disobedience (Bernhard et al., 2006, p. 912).

The "we" versus "them" divide, emphasised in the classical studies on parochial altruism, has been analysed from a more nuanced angle with regard to conflicting identities and complex diversities. Kustov has recently proven that parochial altruism is what gives motivational power to conflicting identities and triggers important political cleavages (Kustov, 2020). Buhari-Gulmez et al. (2020) make a reference to internal divisions and divergent directions in the case of European integration. They put forward a four-fold 
taxonomy of Europe's multiple transformation paths ("many Europes"). "Parochial" Europe, which is "unmaking European integration and transforming Europe along (micro)nationalist lines" is one of the four facets of the transformation of contemporary European politics and society. Parochial Europe is nested in the conventional nation-state model which advocates the pre-eminence of national sovereignty, territorial jurisdiction and state borders. Vertical dependencies are essentially unwelcome and contested. Supranational powers and mechanisms are denounced as hegemonic, elitist, and even detrimental. State authorities at the central level are criticized for excessive fiscalism, cumbersome bureaucracy, and disregard for local affairs. Sometimes, in the context of EU politics, they are blamed for approving the "Brussels' dictatorship" and neglecting "genuine" national interests: "Rather than a civilizationist discourse for Europe-wide harmony, Parochial Europe resorts to nationalist, populist and divisive rhetoric seeking nation-wide harmony without European interference" (Buhari-Gulmez \& Gulmez, 2020, p. 7).

Buhari-Gulmez and Gulmez (2020, p. 9) argue that nationalist discourse and critical attitudes towards supranational integration, which characterize parochialism, should not be identified completely with antiEuropeanism or hard Euroscepticism. They are often more nuanced, based on selectivity or the relativisation of integrationist policies and mechanisms. They stem from rationalized, nation-centred, even egoistic prerequisites, such as economic interest, political influence, or religious imperatives. Hence, parochial Europe inspires instrumental loyalties which reward provincial actors for their care for local resources by means of a specific "parochial entrepreneurship." Practical goals, usually political and economic ones, are often pursued under the cover of the outspoken contestation of supranationalist and cosmopolitan ideas with the use of a specific discourse.

The linguistic factor is relevant for in-group interactions and inter-group communication. The language of messages circulated within a local community seeks to augment the group identity and value orientation. It may tend to emphasise exclusive contents and favour a specific vernacular. As to the latter, Leigh (2000) warns that the received meaning of the messages expressed through or embedded in various parochial behaviours may sometimes be found offensive by external audiences. Terminology is among the key tenets of Sartori's conceptualisation of parochialism. He conceived parochialism as "single-country studies in vacuo, that purely and simply ignore the categories established by general theories and/or by comparative frameworks of analyses, and thereby unceasingly invent, on the spur of the moment, an ad hoc, self-tailored terminology" (Sartori, 1991, p. 247). The argument concerning the total neglect of categories established by general theories and comparative frameworks is particularly strong in the context of the discursive and descrip- tive features of parochial communication. Sartori (1991, p. 248) notes that parochialism causes mislabelling and accepts misnomers.

The word "misnomer" refers to a name or term that is wrong or inappropriate for the thing or person it describes. It comes from the Old French mesnommer, which meant "to name wrongly." According to Webster's New World Dictionary of the American Language, the noun misnomer refers to: " 1 . a) the act of applying a wrong name or epithet to some person or thing $b$ ) such a name or epithet 2 . an error in naming a person or place in a legal document" (Guralnik, 1986, p. 909).

The use of a misnomer may presumably be regarded as a mistake, although it should not be used as a synonym for this. It applies to a specific kind of mistake, that which results from a misunderstanding, poor knowledge, false analogy, or bad intentions. Hence, it can be either accidental or, more often, premeditated.

In parochial discourse, misnomers are used to simplify and even vulgarize complex diversities and multidimensional processes, particularly in the realm of politics. Hadland (2002, p. 41) claims that "misnomers play a central role in the battle for vocabulary in political speech." Misnomers often serve to consolidate the public around catchy words, "headlines" which offer a straightforward and immediate explanation of topical problems.

Rancière (1992) holds that misnomers are policy instruments used to deny a true identity to an individual. He writes: "Politics is about 'wrong' names-misnomers that articulate a gap and connect with a wrong" (Rancière, 1992, p. 62). Misnomers are intended to produce subjectivization (subjectification) by forming one's identity in relation to others' identities (Rancière, 1999, pp. 35-36). Rancière illustrated this practice with reference to immigrants in France in the 1960s. The category "immigrant" was transformed over time and-due to racist and xenophobic tendencies, as well as to problems raised by the immigrant population-got a new connotation, identified with feelings of fear and rejection (Rancière, 1992, p. 63). Recently that practice was noted by Stierl (2019, pp. 43-44) in the context of the migrant crisis in Europe.

In parochial politics misnomers serve a dual role: They enhance populist "othering" (Benveniste et al., 2017, pp. 54-61) in public discourse and consolidate the indigenous population around the exclusionary discursive practice of making refugees "disappear" (Chandler, 2013, pp. 39, 45-46; Macklin, 2005). The latter role entails an active engagement of predominant actors (political leaders, government officials, state-controlled media tycoons) in the erasure of the refugees from official discourse.

\section{Post-2015 Anti-Migration Discourses in the Visegrad Four: Misnaming the Refugee}

The slow yet constant decline of socialist and liberal parties in the 2010s in the four East-Central European 
countries opened a space for conservative, nationalist and populist forces, which either won popular support sufficient to form a government or mobilised a considerable proportion of the citizenry around a nationalist or populist discourse, exerting therefore intense pressure on the ruling parties and framing domestic politics in an ethnopolitical context (Agh, 2015; Bauerova, 2018; Czarnecka, 2018; Koß \& Séville, 2020). Even though migration policies have accompanied the social and economic development of the four Visegrad countries in recent decades, they have been revised and modified by the nationalist-populist governments which took power in the 2010s (Bugaric \& Kuhelj, 2018; Havlík, 2019; Sadurski, 2019; Vachudova, 2019). The concept of "illiberal" democracy, propagated by the Hungarian Prime Minister Viktor Orbán, added impetus to the populist and nationalist discourse, and enabled the emergence of migration issues in the national and security contexts (Buzogány \& Varga, 2018; Halmai, 2019; Lorenz \& Anders, 2021).

The surge of immigration and massive inflow of refugees into Europe in $\mathbf{2 0 1 5}$ greatly contributed to the display of the migration question as a political priority and as a security issue. Even though the Visegrad Four did not absorb a significant number of refugees, with the exception of Hungary in 2015, it being an EU "frontline" state perceived as a corridor to the rich countries of the western part of Europe (mostly Germany and Sweden), the panic over the wave of migrants and refugees hit the Visegrad Four as well.

The open attitude towards refugees presented by many EU member states (with Germany practicing Wilkommenskultur at the forefront) contrasted sharply with the asylum policies of the Visegrad Four, which were based on a restrictive approach and a relatively low level of approval measured by the number of positive decisions on asylum applications (Klaus, 2017; Krastev, 2017).

The terrorist assault on the Charlie Hebdo newspaper office in Paris in January 2015 triggered defensive and exclusionary reactions throughout the East-Central European countries. Fear and anxiety were channelled into mobilisation against immigrants and Muslims-two categories identified with the perpetrators of the terrorist attack. Immediately after the Charlie Hebdo shooting, Prime Minister Viktor Orbán declared that Hungary would not accept any migrants ("Orbán villás nyelven," 2015). He said: "The best immigrant is one who does not come here at all" (Orbán, 2016). Consequently, the Hungarian government adopted a hawkish posture towards immigrants in Europe (Glied, 2020, p. 38). That anti-migrant rhetoric was fuelled by the surge of the migration crisis in mid-2015 and a massive influx of refugees into Hungary.

The arrival of nationals from Muslim countries the Middle East and South Asia, and their immediate claim for the status of international refugee, alarmed the Hungarian authorities and awakened nationalist parties in the other Visegrad Four. International obligations derived from the Geneva Convention on Refugees and enshrined in European law (European Convention on Human Rights, EU Charter of Fundamental Rights, EU asylum system) required that the national authorities comply with international standards of protection for asylum seekers. In addition, these arrangements set the minimum standard of treatment of refugees, determined their juridical status, and, most importantly, opened up the possibility of applicants remaining in a given territory either permanently or until an alternative solution is found. Lastly, international legal standards make governments guarantee the right to effectively claim international protection without obstructions or undue delay. Accordingly, Orbán did not hesitate to declare that "we pursue a migration policy which of course grants political refugees all the possibilities afforded by international law, but which does not allow anyone else in" (Orbán, 2016).

Therefore, denying people the ontological status of refugee was the simplest way of containing the incoming asylum seekers and stripping them of the right to international protection. This was made by a discursive shift in official migration discourse using the word "refugee" as a misnomer. Consequently, a widespread tendency to replace it with other synonymous or euphemistic terms led to a recontextualization of the discourse on migration along the lines of the political imperatives derived from the dominant nationalist and populist rhetoric of the ruling party.

Despite over 177,000 applications for refugee status were submitted to the Hungarian authorities throughout 2015, the Hungarian government insisted on labelling refugees as "economic migrants" (megélhetési bevándorlók) and emphasized the burden they placed on the Hungarian state and economy (Uitz, 2020, p. 17). Viktor Orbán denied, on many occasions, the existence of a serious humanitarian and legal issue of international refugees. He announced that "we are not witnessing the arrival of refugees, but a Europe being threatened by mass migration" ("PM Orbán asks," 2016). He added: "This is not a refugee crisis. This is a mass migratory movement composed of economic migrants, refugees, asylum seekers and also foreign fighters. This is an uncontrolled and unregulated process" (UN, 2015). He even suggested that the figure of the refugee is a form of disguise, hiding an individual's real nature, displaying those external features and behavioural traits which present the migrant as if he or she were a refugee. In the national consultation letter on immigration and terrorism, issued in May 2015, Orbán emphasized the following: "Economic immigrants cross the borders illegally, and while they act as refugees, they come for social benefits and work opportunities" (Orbán as cited in Marton, 2017, p. 35).

The locution "economic migrant" was made widespread in the official language of the Visegrad Four governments, as well as at the level of the Visegrad Group. The prime ministers of the Visegrad Four, in a joint statement on migration adopted in July 2017, 
declared that "we believe that the precondition to any efficient strategy related to mixed migratory flows is to distinguish between genuine asylum seekers and economic migrants" (V4 Connects, 2017). That position was confirmed in a letter from the Prime Ministers of the Visegrad Four to Italian Prime Minister Paolo Gentiloni of 19 July 2017 addressing the pressure that migration was causing; the heads of the Visegrad Four governments stated that "the vast majority of the mixed migration flows are composed of economic migrants" (Visegrad Group, 2017). It is significant that the documents adopted by the Visegrad Group about refugees and migration since the outbreak of the crisis in Europe have never contained the very term "'refugee," substituting it-if required-with "asylum seeker" or, incidentally, "people who satisfy asylum criteria" and "those in genuine need of international protection."

The narrative based on misnaming the refugee and replacing him or her with an "economic migrant" went viral among top government officials in the Visegrad Four. Slovak Prime Minister Robert Fico ascertained in late 2015 that "ninety-five percent of those arriving in Slovakia were economic migrants and not refugees" (Stepper, 2016, p. 66). A similar differentiation between refugees (uprchliky) and migrants (migranty) was adopted by the Czech government led by Prime Minister Andrej Babiš (Hampejs, 2018; Jelínková, 2019). Polish Prime Minister Ewa Kopacz, representing the liberal Civic Platform government which was replaced in November 2015 by Law and Justice (PiS), expressed the reservation, in the context of EU plans for a refugee relocation system, that Poland was committed to host "as many refugees, but not economic migrants, as we can handle" (Potyrała, 2016, p. 80). During a parliamentary debate on the migration crisis in Europe, Jarosław Kaczyński, the leader of the PiS, said "it is necessary to clearly distinguish between refugees, who are actually fleeing the war, and economic emigrants. It is necessary to differentiate between them" (Kaczyński, 2015).

Marton (2017, pp. 38-39) aptly captures the semiotic context of the migration-related key words. He clarifies this in the following terms:

Using the expression "economic immigrant" instantly gives away the intentions of the government on how they want Hungarians to see refugees: People who come for economic purposes, putting in danger the workplace and wellbeing of Hungarians. Even 'immigrant' (migráns in Hungarian) as a choice of word evokes mistrust, as 'immigrant' is a foreign word in Hungarian, unfamiliar and not widely used, therefore it serves the purpose of alienation and negative connotation towards the subject of the word. In opposition, "refugee" (menekült in Hungarian) is a more familiar word for Hungarian citizens and channels a positive connotation (a person who is running away from something and needs some sort of an aid).

\section{An Ethno-Nationalistic Misnomer: Denigrating "Arabs"}

Religious and cultural factors have been yet another trait of parochial politics in the Visegrad Four. Antipathy towards "others" ("strangers," "aliens") was extended to the migration conundrum throughout Europe. The highlighting of national values, cultivating local traditions and "closing ranks," reactions typical for parochial altruism, have reflected hypersensitivities to migrants' customs and behaviours. Prospects for hosting large groups of refugees and granting them official protection and assistance were damaged by the governments of the Visegrad Four with growing acceptance from their nationals (Pachocka, 2016). The goodness of "welcome politics" and generosity towards refugees were conceived as erroneous and unfounded, evidencing political myopia (Pacek, 2020, pp. 95-96).

Factual or alleged cases of wrongdoing and offenses committed by immigrants were interpreted as: (1) disregard for hospitality and assistance provided by the hosting states; (2) the lack of adaptability to local conditions due to cultural, religious and language differences; and (3) a sense of "impunity" due to lengthy procedures, ineffective mechanisms for returning unsuccessful applicants and a relatively wide scope of tolerance to irregular migrants. Therefore, the religious and ethnic distinctiveness of others was contrasted with parochial virtues and the goodness of "NIMBY-ism"-“Not In My Back Yard" (Hunter \& Hutchinson, 1994, p. 1164).

The prevalence of nationals of Syria, Afghanistan, and Pakistan in the huge wave of refugees that reached Europe in the mid-2010s made the migration problem commonly identified with massive flow of Muslims ("Arabs"). The xenophobic narrative constructed by ethno-nationalistic actors in the Visegrad Four portrayed refugees as barbarians who flood the European countries, undermine the public order, and abuse their right to international humanitarian assistance (Kalmar, 2018; Kende \& Krekó, 2020; Pickel \& Öztürk, 2018). Viktor Orbán, in an interview for the German daily Bild (Blome \& Stenzel, 2018), said: “We don't see these people as Muslim refugees. We see them as Muslim invaders....We believe that a large number of Muslims inevitably lead to parallel societies, because Christian and Muslim society will never unite." In addition, he argued against the reception of Muslim migrants: "If you take masses of non-registered immigrants from the Middle East into your country, you are importing terrorism, crime, anti-Semitism, and homophobia," he said in the interview (Blome \& Stenzel, 2018). In a similar mood Robert Fico, the leader of the then-ruling Smer-SD in Slovakia, asserted that the multiculturalism project had failed, and that Slovakia was reluctant to see the arrival of large numbers of Muslims, the erection of mosques, and changes in the culture of the country (Nyzio, 2017, p. 51). The Slovak prime minister claimed that migrants coming from the Middle East posed a serious threat to 
his country. He bluntly said that "it may look strange but sorry....Islam has no place in Slovakia" (Chadwick, 2016). He declared firmly that his government "will never make a voluntary decision that would lead to formation of a unified Muslim community in Slovakia" (Reuters Staff, 2016).

Czech President Miloš Zeman warned Europe of an "organised invasion" of migrants and advised young men coming from the Middle East to take up arms and fight against the Islamic State instead of heading for Europe to seek asylum ("Czech president," 2015). He also said that the migration wave in Europe in 2015 was made up of Islamists. He added: "We should make sure that they will not even be able to enter our territory" ("Czech President Miloš Zeman", 2015). Petr Fiala, the leader of the right-ofcentre Civic Democratic Party (ODS), assured Czech citizens that "radical Islam is a threat. Uncontrolled masses of refugees do constitute a security threat" ("Prior to Angela Merkel's," 2016). In a similar vein, another influential Czech politician, Prime Minister Andrej Babiš, was said, prior to the election of 2016, to have taken "a sharply defined stance against continuing immigration... and against the potential formation of a large Muslim community in the Czech Republic" (Klima, 2016).

The popular dislike to Muslims among the ruling politicians correlated with the attitudes of the public opinion towards the migration crisis and foreigners (Simonovits \& Szeitl, 2019). Surveys conducted in the 2010s proved that nationals of the Visegrad Four strongly dislike ethnic and religious communities, such as Muslims (commonly identified with "Arabs"), Roma and Jews. The antipathy to Roma and Muslims has remained strong since 2002. A surge of anti-Muslim and anti-Arab sentiment has been observed since mid-2015. In Poland, antipathy to "Arabs" reached the level of 67\% in March 2016 and was maintained in the following years, amounting to 65\% in January 2019 (CBOS, 2019 , p. 2). Accordingly, most respondents (64\%) highlighted intolerance and aggressive features of Islam: 57\% thought that it encourages violence and $51 \%$ believed that Muslims approve violent actions against other religions (CBOS, 2015). In the Czech Republic, according to an opinion poll conducted in March 2017 by the Czech Public Opinion Research Centre, antipathy to "Arabs" was declared by $75 \%$ of the respondents (Colborne, 2017). This negative attitude decreased slightly later, reaching in March 2020 the level 66-69\% (Centrum pro výzkum veřejného mínění, 2020). A similar level of negative attitudes towards Muslims was displayed in an opinion poll in Hungary in early 2016: $72 \%$ of the respondents declared an unfavourable view of Muslims in their country (Manevich, 2016). In Slovakia, this level is slightly lower: $54 \%$ of the respondents to a poll carried out in December 2017 declared they "did not want to have a Muslim as a neighbour" ("Čoraz viac Slovákov," 2017).

The above attitudes reflect the application of some principles of parochial politics to migration policy. Nation and faith were chosen as criteria of belonging and identity-shaping with direct reference to indigenisation and religious exclusionism. The figure of a refugee misnamed as an "Arab" and associated with the "alien," or the "other," was inculcated in the public consciousness in the context of a parochial sense of ontological insecurity.

\section{Conclusions}

The exclusionary, deterrent approach to immigrants and refugees arriving in Europe from the beginning of the 2010s was one of the most remarkable features of European politics at that time. The anti-immigrant narrative became a permanent part of everyday communication and public discourse. Though not particularly unique when compared to earlier immigration waves in Europe or to some EU member states, the Visegrad Four deserve a critical assessment regarding the outburst of aversion and hostility towards migrants coinciding with the denial of refugees as migrants deserving protection based on international humanitarian law.

This may be partly explained by ideological factors. The liberal model was challenged by, and-in the case of Hungary and Poland-substituted with a specific illiberal project entailing the restoration of traditionalist patterns of parochial communities mobilized by the top-down, persuasive transmission of a strange blend of nationalist, xenophobic, anti-cosmopolitan, anti-elitist, and conspiratorial views. That project also underlaid the ideological construction of immigration policy and influenced attitudes towards migrants and refugees.

Concurrently, it must be pointed out that the values and norms of European Union politics, especially those concerning the freedom of movement of persons, were used selectively to justify and legitimize the Visegrad Four's ethnocentric postures via integrationist policies and mechanisms which accentuated protective measures and security imperatives. The parochial realms cultivated in the Visegrad Four were intimately tied to their territories, enhancing therefore the deterrent and repulsive functions of border, immigration, and asylum policies.

The above analysis has shown that parochial politics petrifies the traditional cleavages at the supra-local level, reinforcing simultaneously the sense of provincial altruism and hostility towards the others. Discourse and communication play a critical role in augmenting exclusionary attitudes and constructing a reversed image of transnational processes. The use of misnomers has been exemplified by nationalistic and xenophobic rhetoric in excluding refugees from the humanitarian regime or denigrating selected religious or ethnic groups.

\section{Acknowledgments}

The open access license and publishing fee of the publication was funded by the Priority Research Area Society of the Future under the program "Excellence InitiativeResearch University" at the Jagiellonian University in Krakow. 


\section{Conflict of Interests}

The author declares no conflict of interests.

\section{References}

Agh, A. (2015). De-Europeanization and de-democratization trends in ECE: From the Potemkin democracy to the elected autocracy in Hungary. Journal of Comparative Politics, 8(2), 4-26.

Almond, G. A., \& Verba, S. (1989). The civic culture. Political attitudes and democracy in five nations. SAGE.

Bauerova, H. (2018). Migration policy of the V4 in the context of migration crisis. Politics in Central Europe, 14(2), 99-120.

Bauman, Z. (2004). Europe: An unfinished adventure. Polity Press.

Bello, V. (2017). International migration and international security. Why prejudice is a global security threat. Routledge.

Benveniste, A., Lazaridis, G., \& Puurunen, H. (2017). Populist othering and Islamophobia. In G. Lazaridis \& G. Campani (Eds.), Understanding the populist shift: Othering in a Europe in crisis (pp. 50-69). Routledge.

Bernhard, H., Fischbacher, U., \& Fehr, E. (2006). Parochial altruism in humans. Nature, 442(7105), 912-915.

Blome, N., \& Stenzel, C. (2018, January 7). “Ihr wolltet die Migranten, wir nicht!" ["You wanted the migrants, we didn't"]. Bild. https://www.bild.de/bild-plus/ politik/ausland/viktor-orban/orban-interview54403736, jsRedirectFrom=conversionToPay, view= conversionToPay.bild.html

Bowles, S., \& Gintis, H. (2004). Persistent parochialism: Trust and exclusion in ethnic networks. Journal of Economic Behavior \& Organization, 55(1), 1-23.

Bugaric, B., \& Kuhelj, A. (2018). Varieties of populism in Europe: Is the rule of law in danger? Hague Journal on the Rule of Law, 10(1), 21-33.

Buhari-Gulmez, D., \& Gulmez, S. B. (2020). Theorizing many Europes: A four-fold taxonomy. European Politics and Society. Advance online publication. https:// doi.org/10.1080/23745118.2020.1842697

Buhari-Gulmez, D., Kaunert, C., \& Gulmez, S. B. (2020). Transforming Europe through crises: Thin, thick, parochial and global dynamics. European Politics and Society. Advance online publication. https://doi.org/ 10.1080/23745118.2020.1842696

Buzogány, A., \& Varga, M. (2018). The ideational foundations of the illiberal backlash in central and eastern Europe: The case of Hungary. Review of International Political Economy, 25(6), 811-828.

CBOS. (2015). Attitude to Islam and Muslims (Report No. 037). http://www.cbos.pl/EN/publications/ reports/2015/037 15.pdf

CBOS. (2019). Attitude to other nationalities (Report No. 017). https://www.cbos.pl/EN/publications/ reports/2019/017_19.pdf

Centrum pro výzkum veřejného mínění. (2020). Toler- ance $k$ vybraným skupinám obyvatel-březen 2020 [Tolerance of selected population groups-March 2020]. https://cvvm.soc.cas.cz/media/com_form2 content/documents/c6/a5202/f77/ov200430.pdf

Chadwick, V. (2016, May 26). Robert Fico: "Islam has no place in Slovakia." Politico. https://www.politico.eu/ article/robert-fico-islam-no-place-news-slovakiamuslim-refugee

Chandler, D. (2013). Rethinking the subject of human security. In M. K. Pasha (Ed.), Globalization, difference, and human security (pp. 38-50). Routledge.

Choi, J.-K., \& Bowles, S. (2007). The coevolution of parochial altruism and war. Science, 318(5850), 636-640.

Colborne, M. (2017, April 27). Surveying some surveys: Czechs \& refugees, immigrants and Islam. Michael Colborne. https://michaelcolborne.com/2017/04/ 27/surveying-some-surveys-czechs-refugeesimmigrants-and-islam

Čoraz viac Slovákov nechce susedit' s moslimom či homosexuálom [More and more Slovaks do not want a Muslim or a homosexual as neighbours]. (2017, December 18). Aktuality. https://www.aktuality.sk/ clanok/548957/coraz-viac-slovakov-nechce-susedits-moslimom-ci-homosexualom

Czarnecka, A. (2018). Migration crisis in 2013 as an example of the lack of political cohesion of EU countries. Torun International Studies, 1(11), 135-145.

Czech President Miloš Zeman: The immigrants are islamists. They are trying to subjugate Europe. (2015, November 5). Britske listy. https://blisty.cz/art/ 79737-czech-president-milos-zeman-theimmigrants-are-islamists-they-are-trying-tosubjugate-europe.html

Czech president: Migrants should be fighting Isis, not "invading" Europe. (2015, December 27). The Guardian. https://www.theguardian.com/world/ 2015/dec/27/czech-president-migrants-should-befighting-isis-not-invading-europe

De Dreu, C. K., Balliet, D., \& Halevy, N. (2014). Parochial cooperation in humans: Forms and functions of selfsacrifice in intergroup conflict. Advances in Motivation Science, 1, 1-47.

De Dreu, C. K., Dussel, D. B., \& Velden, F. S. T. (2015). In intergroup conflict, self-sacrifice is stronger among pro-social individuals, and parochial altruism emerges especially among cognitively taxed individuals. Frontiers in Psychology, 6(572), 1-9.

De Master, S., \& Le Roy, M. K. (2000). Xenophobia and the European Union. Comparative Politics, 32(4), 419-436.

De Wilde, P. (2011). No polity for old politics? A framework for analyzing the politicization of European Integration. Journal of European Integration, 33(5), 559-575.

De Wilde, P., \& Zürn, M. (2012). Can the politicization of European integration be reversed? Journal of Common Market Studies, 50(1), 137-153. 
Della Porta, D., \& Diani, D. (2006). Social movements: An introduction (2nd ed.). Blackwell Publishing.

Gibson, R. K. (2002). The growth of anti-immigrant parties in Western Europe. Edwin Mellen Press.

Glied, V. (2020). The populist phenomena and the reasons for their success in Hungary. Politics in Central Europe, 16(1S), 23-45.

Grande, E., \& Hutter, S. (2016). Introduction: European integration and the challenge of politicisation. In S. Hutter, E. Grande, \& H. Kriesi (Eds.), Politicising Europe. Integration and mass politics (pp. 3-31). Cambridge University Press.

Guralnik, D. B. (Ed.). (1986). Webster's new world dictionary of the American language (2nd ed.). Prentice Hall Press.

Hadland, E. (2002). The battle for vocabulary in political speech: Historical perspective on misnomers, euphemisms, aspersions, and shibboleths. Tokyo University of Information Sciences Research Review, 5(2), 39-60.

Halmai, G. (2019). Illiberalism in East-Central Europe (EUI Working Paper LAW 2019/05). European University Institute.

Hampejs, M. (2018, December 18). Uprchlíky ano, migranty ne. ČSSD přesvědčila Babiše k prijetí paktu o uprchlících [Refugees yes, migrants no. The ČSSD persuaded Babiš to accept the pact on refugees]. Lidovky.cz. https://www.lidovky.cz/svet/uprchlikyano-migranty-ne-cssd-presvedcila-babise-k-prijetipaktu-o-uprchlicich.A181218_143213_In_zahranici_ mha

Hargreaves, A. G., \& Leaman, J. (Eds.). (1995). Racism, ethnicity and politics in contemporary Europe. Edward Elgar Publishing.

Havlík, V. (2019). Technocratic populism and political illiberalism in Central Europe. Problems of PostCommunism, 66(6), 369-384.

Hunter, Jr., M. L., \& Hutchinson, A. (1994). The virtues and shortcomings of parochialism: Conserving species that are locally rare, but globally. Common Biology, 8(4), 1163-1165.

Jelínková, M. (2019). A refugee crisis without refugees: Policy and media discourse on refugees in the Czech Republic and its implications. Central European Journal of Public Policy, 13(1), 33-45.

Kaczyński, J. (2015). Wypowiedzi na posiedzeniach Sejmu, Posiedzenie nr $100 \mathrm{w}$ dniu 16-09-2015 [Statements made at the sessions of the Sejm, Session no. 100 on September 16, 2015]. http:// sejm.gov.pl/Sejm7.nsf/wypowiedz.xsp?posiedzenie= $100 \&$ dzien $=1 \&$ wyp $=7 \&$ view $=1$

Kalmar, I. (2018). "The battlefield is in Brussels": Islamophobia in the Visegrád Four in its global context. Patterns of Prejudice, 52(5), 406-419.

Kende, A., \& Krekó, P. (2020). Xenophobia, prejudice, and right-wing populism in East-Central Europe. Current Opinion in Behavioral Sciences, 34, 29-33.

Klaus, W. (2017). Closing gates to refugees: The causes and effects of the 2015 "migration crisis" on border management in Hungary and Poland. Yearbook of the Institute of East-Central Europe, 15(3), 11-34.

Klima, M. (2016, September 7-10). The private business firm party-As a sub-category of the modern elite party. Movement ANO 2011-The case of the Czech Republic [Paper presentation]. ECPR General Conference, Prague, Czech Republic.

Koß, M., \& Séville, A. (2020). Politicized transnationalism: The Visegrád Countries in the refugee crisis. Politics and Governance, 8(1), 95-106.

Krastev, I. (2017). The refugee crisis and the return of the East-West divide in Europe. Slavic Review, 76(2), 291-296.

Krippendorff, K. (2003). Content analysis: An introduction to its methodology (2nd ed). SAGE.

Krzyżanowski, M. (2017). Discursive shifts in ethnonationalist politics: On politicization and mediatization of the "refugee crisis" in Poland. Journal of Immigrant \& Refugee Studies, 16(1/2), 76-96.

Krzyżanowski, M., Triandafyllidou, A., \& Wodak, R. (2018). The mediatization and the politicization of the "refugee crisis" in Europe. Journal of Immigrant \& Refugee Studies, 16(1/2), 1-14.

Kubik, J. (2009). Ethnography of politics: Foundations, applications, prospects. In E. Schatz (Ed.), Political ethnography: What immersion contributes to the study of power (pp. 25-52). University of Chicago Press.

Kustov, A. (2020). Borders of compassion: Immigration preferences and parochial altruism. Comparative Political Studies. Advance online publication. https:// doi.org/10.1177/0010414020938087

Leigh, J. (2000). Implications of universal and parochial behavior for intercultural communication. Intercultural Communication, 2000(4). http://mail.immi.se/ intercultural/nr4/leigh.htm

Leudar, I., Hayes, J., Nekvapil, J., \& Turner Baker, J. (2008). Hostility themes in media, community and refugee narratives. Discourse \& Society, 19(2), 187-221.

Leudar, I., Marsland, V., \& Nekvapil, J. (2004). On membership categorisation: "Us," "them" and "doing violence" in political discourse. Discourse \& Society, 15(2/3), 243-266.

Levy, C. (2010). Refugees, Europe, camps/state of exception: "Into The Zone," the European Union and extraterritorial processing of migrants, refugees, and asylum-seekers (theories and practice). Refugee Survey Quarterly, 29(1), 92-119.

Long, K. (2013). When refugees stopped being migrants: Movement, labour and humanitarian Protection. Migration Studies, 1(1), 4-26.

Lorenz, A., \& Anders, L. A. (Eds.). (2021). Illiberal trends and anti-EU politics in East Central Europe. Palgrave Macmillan.

Macklin, A. (2005). Disappearing refugees: Reflections on the Canada-US Safe Third Country Agreement. Columbia Human Rights Law Review, 36, 365-426. 
Malešević, S. (2004). The sociology of ethnicity. SAGE.

Manevich, D. (2016). Hungarians share Europe's embrace of democratic principles but are less tolerant of refugees, minorities. Pew Research Center. http://www.pewresearch.org/fact-tank/2016/09/ 30/hungarians-share-europes-embrace-ofdemocratic-principles-but-are-less-tolerant-ofrefugees-minorities

Marton, Z. (2017). Populism and the refugee crisis: The communication of the Hungarian government on the European refugee crisis in 2015-2016 [Master's Thesis, Faculty of Culture and Society, Malmö University]. https://www.diva-portal.org/smash/get/diva2: 1482071/FULLTEXT01.pdf

Menéndez, A. J. (2016). The refugee crisis: Between human tragedy and symptom of the structural crisis of European integration. European Law Journal, 22(4), 388-416.

Morsut, C., \& Kruke, B. I. (2018). Crisis governance of the refugee and migrant influx into Europe in 2015: A tale of disintegration. Journal of European Integration, 40(2), 145-159.

Niemann, A., \& Zaun, N. (2018). EU refugee policies and politics in times of crisis: Theoretical and empirical perspectives. JCMS: Journal of Common Market Studies, 56(1), 3-22.

Nyzio, A. (2017). The second revival? The Visegrád group and the European migrant crisis in 2015-2017. Politeja, 50(5), 47-98.

Orbán villás nyelven beszél a bevándorlókról [Orbán speaks with a forked tongue about immigrants]. (2015, January 24). Népszava. https://nepszava.hu/ 1046237_orban-villas-nyelven-beszel-abevandorlokrol

Orbán, V. (2016, January 22). The route may move in any direction, but one thing is certain: It will not go through Hungary [Speech transcript]. About Hungary. http://abouthungary.hu/speeches-and-remarks/ the-route-may-move-in-any-direction-but-onething-is-certain-it-will-not-go-through-hungary

Pacek, M. (2020). Polish migration policy in the context of the migration crisis. Studia Europejskie-Studies in European Affairs, 3, 85-108.

Pachocka, M. (2016). Understanding the Visegrad group states' response to the migrant and refugee crises 2014+ in the European Union. Yearbook of Polish European Studies, 19, 101-132.

Parochialism. (2005). In Oxford Dictionary of English (3rd ed.). Oxford University Press.

Pelinka, A. (2013). Right-wing populism: Concept and typology. In R. Wodak, M. KhosraviNik, \& B. Mral (Eds.), Right-wing populism in Europe: Politics and discourse (pp. 3-22). Bloomsbury.

Pickel, G., \& Öztürk, C. (2018). Islamophobia without Muslims? The "contact hypothesis" as an explanation for anti-Muslim attitudes-Eastern European societies in a comparative perspective. Journal of Nationalism, Memory \& Language Politics, 12(2), 162-191.
PM Orbán asks "shall we live in slavery or freedom?" (2016, March 17). About Hungary. http:// abouthungary.hu/prime-minister/pm-orban-asksshall-we-live-in-slavery-or-freedom

Potyrała, A. (2016). Poland towards the migration crisis of 2015-2016. Przeglad Politologiczny, 2, 75-87.

Poulson, S. C., \& Campbell, C. (2010). Isomorphism, institutional parochialism, and the sociology of religion. American Sociologist, 41(1), 31-47.

Prior to Angela Merkel's visit to Prague, Czech politicians have condemned her pro-refugee policy. (2016, August 20). Britske listy. https://blisty.cz/art/83404prior-to-angela-merkel-s-visit-to-prague-czechpoliticians-have-condemned-her-pro-refugeepolicy.html

Rancière, J. (1992). Politics, identification, and subjectivization. October, 61, 58-64.

Rancière, J. (1999). Disagreement. Politics and philosophy. University of Minnesota Press.

Reuters Staff. (2016, January 7). Slovak PM says will fight to keep immigration to a minimum. Reuters. https://www.reuters.com/article/uk-europemigrants-slovakia-idUKKBNOUL1ZK20160107

Rusch, H. (2014). The evolutionary interplay of intergroup conflict and altruism in humans: A review of parochial altruism theory and prospects for its extension. Proceedings of the Royal Society B, 281, Article 20141539. https://royalsocietypublishing.org/doi/ full/10.1098/rspb.2014.1539

Sadurski, W. (2019). Poland's constitutional breakdown. Oxford University Press.

Sartori, G. (1991). Comparing and miscomparing. Journal of Theoretical Politics, 3(3), 243-257.

Schatz, E. (2009). Ethnographic immersion and the study of politics. In E. Schatz (Ed.), Political ethnography: What immersion contributes to the study of power (pp. 1-22). University of Chicago Press.

Schwartz-Shea, P., \& Yanow, D. (2012). Interpretive research design: Concepts and processes. Routledge.

Sigona, N. (2018). The contested politics of naming in Europe's "refugee crisis." Ethnic and Racial Studies, 41(3), 456-460.

Simonovits, B., \& Szeitl, B. (2019). Attitudes towards migration and migration policies in Hungary and Europe (2014-18). In I. G. Tóth (Ed.), Hungarian social report 2019 (pp. 295-313). TARKI. https://www. tarki.hu/sites/default/files/2019-02/295_313_ Simonovits_Szeitl.pdf

Stepper, P. (2016). The Visegrad group and the EU agenda on migration: A coalition of the unwilling? Corvinus Journal of International Affairs, 1(1), 62-82.

Stierl, M. (2019). Migrant resistance in contemporary Europe. Routledge.

Taras, R. (2009). Europe old and new: Transnationalism, belonging, xenophobia. Rowman \& Littlefield Publishers.

Tilly, C. (1986). The contentious French. Harvard University Press. 
Uitz, R. (2020). Reinventing Hungary with revolutionary fervor: The declaration of national cooperation as a readers' guide to the Fundamental Law of 2011. In J. M. Kovács \& B. Trencsényi (Eds.), Brave new Hungary. Mapping the "system of national cooperation" (pp. 9-28). Lexington Books.

UN. (2015, September 30). Statement by H.E. Mr. Viktor Orbán Prime Minister of Hungary at the High Level side event on "Strengthening cooperation on migration and refugee movements in the perspective of the new development agenda." https://www.un.org/en/ development/desa/population/migration/events/ ga/2015/docs/statements/HUNGARY.pdf

V4 Connects. (2017). Joint statement by the prime ministers of V4 countries on migration, 19 July 2017, Budapest. https://www.vlada.cz/assets/mediacentrum/aktualne/Joint-Statement-by-the-PrimeMinisters-of-V4-Countries-on-migration.pdf

Vachudova, M. A. (2019). From competition to polarization in Central Europe: How populists change party systems and the European Union. Polity, 51(4), 689-706.
Van der Brug, W., Fennema, M., \& Tillie, J. (2000). Antiimmigrant parties in Europe: Ideological or protest vote? European Journal of Political Research, 37(1), 77-102.

Visegrad Group. (2017). Letter from the prime ministers of the Visegrad countries to the Italian prime minister. https://www.visegradgroup.eu/download.php? docID $=321$

Wistrich, R. S. (1999). Xenophobia and antisemitism in the new Europe: The case of Germany. In R. S. Wistrich (Ed.), Demonizing the other. Antisemitism, racism, and xenophobia (pp. 349-363). Routledge.

Wodak, R. (2015). The politics of fear. What right-wing populist discourses mean. SAGE.

Yanow, D. (2000). Conducting interpretive policy analysis. SAGE.

Zetter, R. (1991). Labelling refugees: Forming and transforming a bureaucratic identity. Journal of Refugee Studies, 4(1), 39-62.

Zetter, R. (2007). More labels, fewer refugees: Remaking the refugee label in an era of globalization. Journal of Refugee Studies, 20(2), 172-192.

\section{About the Author}

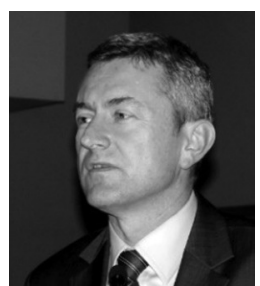

Artur Gruszczak is a professor of social sciences and chair of national security at the Faculty of International and Political Studies, Jagiellonian University in Krakow. His principal interests and research areas include: EU internal security; migration and asylum policies; and the transformation of war. He has co-edited with Paweł Frankowski two volumes: Technology, Ethics and the Protocols of Modern War (Routledge, 2018) and Cross-Disciplinary Perspectives on Regional and Global Security (Palgrave Macmillan, 2018). 